\title{
Preparation of an Amino Acid Based DTPA as a BFCA for Radioimmunotherapy
}

\author{
Kang-hyuk Choi, Young-Don Hong, Mi-Sun Pyun, and Sun-Ju Choi*
}

\author{
Radioisotope R\&D LAB, HANARO Application Research, Korea Atomic Energy Research Institute, Daejeon 305-353, Korea \\ "E-mail: choisj@kaeri.re.kr \\ Received May 29, 2006
}

\begin{abstract}
For the purpose of developing more effective chelating agents, we have synthesized a diethylene triamine pentaacetic acid(DTPA) analogue by using an amino acid. $S$ - $(N$-Boc-aminophenyl $)-C y s(t$-Bu-DTPA) methylester was prepared in 6 steps with total yield of $47.9 \%$. For the sake of introducing a biomolecule to the DTPA derivative, a selective hydrolysis was perfonmed with $3 \mathrm{M} \mathrm{HCl} /$ Ethylacetate $=1: 3\left(25^{\circ} \mathrm{C}, 30 \mathrm{~min}\right.$, vigorous stirring). ${ }^{166} \mathrm{Ho}-\mathrm{Cys}-\mathrm{DTPA}$ and ${ }^{166} \mathrm{Ho}-\mathrm{Biotin}-\mathrm{Cys}-\mathrm{DTPA}$ were prepared by mixing ${ }^{166} \mathrm{Ho}$ with DTPA derivatives at room temp in a $\mathrm{HCl}$ solution $(\mathrm{pH}=5)$ and the radiochemical stabilities $(>99 \%)$ were maintained for over $6 \mathrm{hrs}$ in vitro.
\end{abstract}

Key Words : DTP $\Lambda$ derivative, $\Lambda$ mino acid, ${ }^{166}$ IIo-DTP $\Lambda, B F C \Lambda$, Radioimmunotherapy

\section{Introduction}

In the past decade, many bifunctional chelating agents (BFCAs) have been studied, synthesised and used for radiophanmaceuticals especially for labeling both antibodies and regionally selective drugs. ${ }^{1-10} \mathrm{BFCA}$ means the central molecule, which possesses an additional functional group and ligands, for attaching radiometalnuclides to biomolecules. Ehylenediaminetetraacetic acid (EDTA) and diethylenetriaminepentaacetic acid (DTPA) are commonly used for metal chelating agents and their functionalized ligands have been reported for this purpose. 213

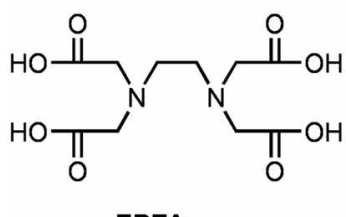

EDTA

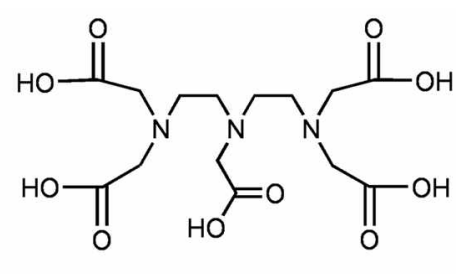

DTPA
A functionalized EDTA was first used for evaluating a scintigraphy, ${ }^{9}$ but its metal complex is unstable for in vivo condition, because EDTA as a hexadentate ligand has an insufficient chelating power at a wide range of the $\mathrm{pH}$. To create an alternative, octadentate ligand DTPA has been used successfully for in vivo application. ${ }^{6.11}$ DTPA shows a specific binding activity to hard lanthanide(III) ions and it is being commercially used e.g. Gd(III)-DTPA as an MRI contrast agent under the name of Magnevist ${ }^{\circledR}$ (Schering, Berlin, Germany.), ${ }^{90}$ Y-DTPA in radiotherapy and ${ }^{117 m}$ Sn-DTPA in the treatment of bone metastasis. ${ }^{13}$ Traditional researches for functionalized DTPA were accomplished by using a DTPA anhydride ${ }^{5-13}$ with the formation of imide or ester. However, there are two disadvantages: one is that an anhydride undergoes an inter molecular cross linking and the other is that one or two of the carboxyl groups of the DTPA are used to introduce an additional functional group. These may cause alleviation of the chelating power, even though side products are formed. To solve these problems, Williams and his coworker described noble DTPA analogues ${ }^{3}$ from Lphenylalanine via $N$-alkylation and John S. Davies reported on a new synthetic method for DTPA derivatives ${ }^{4}$ by using diethylene triamine. These works are useful to help us develop a new bifunctional DTPA for a chelating radiometalnuclide.

We also focused on bioacitve molecules which can bind to DTPA derivatives with a covalent bond as well as a bifunctional DTPA. Avidine $e^{1+16}$ is a glycosylated tetrameric protein with a positive charge which can bind up to 4 molecules of vitamin $\mathrm{H}$ known as $\mathrm{D}$-biotin. The interaction with biotin and avidin is noncovalent but it shows an extremely strong affinity. The affinity constant is $10^{6}$-fold higher than that of the antigen-mAb (monoclonal antibody) interaction. Streptavidin is an analog of avidin with similar characteristics to an avidin-biotin affinity. In radioimmunodiagnosis and radioimmunotherapy, ${ }^{17}$ the pretargeting ${ }^{18.19}$ avidin-biotin or streptavidin-biotin strategy has shown that the target to nontarget radioactivity ratio can be significantly increased.

Our goal is to develop new bifunctional chelating agents which optimized for a use in a pretargeting approach for a radioimmunotheraphy for cancer. To develop new chelating agents, we also focus on the development of DTPA derivatives whose original functional groups are intact. To solve the issues mentioned above, we describe herein the synthesis of a DTPA analogue which is derived from $\mathrm{L}$-cysteine via $\mathrm{N}$ dialkylation. We also show a selective deprotection of the DTPA derivative for introducing biotin to the DTPA.

\section{Experimental Section}

Materials and Reagents. All chemicals and reagents used in the present study were obtained from commercial suppliers and used without any further purification. All the progress of the reaction were monitored by TLC glass sheets 
pre-coated with silica-gel, G-25 $\mathrm{UV}_{25,4}$, Macherey-Nagel Inc. The NMR spectra were recorded with the Varian Gemini $200\left(200 \mathrm{MHz}{ }^{1} \mathrm{H}\right.$, Dongguk. Univ.) and Bruker Avance $500(500 \mathrm{MHz}$, 'H, KRICT, Daejeon) spectrometers. Mass spectra were recorded with the Hewlett Packard HP 1100 series LC/MSD (Chungnam National Univ.) ${ }^{166} \mathrm{Ho}\left(\mathrm{NO}_{3}\right)_{3}$ produced at the Korea Atomic Energy Research Institute (KAERI) was used. Instant thin layer chromatography-silica gel paper (ITLC-SG) was purchased from Gelman Science Inc. (Ann Arbor, USA). The radiolabeling yield was determined by an ITLC scanner (Trance master 200, Berthold). Radioactivity was measured by using an ionizing chamber (Atomlab 200, Bio-dex).

$N, N$-Bis [(tert-butoxycarbonyl)methyl]-2-ethanolamine (1). To tert-butyl bromoacetate $(17.02 \mathrm{~mL}, 115 \mathrm{mmol})$ which was dissolved in DMF $(100 \mathrm{~mL})$ under a $\mathrm{N}_{2}$ condition, $\mathrm{K}_{2} \mathrm{CO}_{3}(12.514 \mathrm{~g}, 125 \mathrm{mmol})$ was added. The reaction mixture was cooled down to $0^{\circ} \mathrm{C}$ and ethanolamine $(2.98$ $\mathrm{mL}, 49.4 \mathrm{mmol}$ ) was added dropwisely for $5 \mathrm{~min}$. The reaction mixture was continuously stirred at $0^{\circ} \mathrm{C}$ for $30 \mathrm{~min}$ and then left overnight at room temp. After an addition of c$\mathrm{NaHCO}_{3}(100 \mathrm{~mL})$ and diethyl ether $(150 \mathrm{~mL})$, the organic layer was separated and washed with $\mathrm{c}-\mathrm{NaHCO}_{3}(50 \mathrm{~mL})$ and with brine $(100 \mathrm{~mL})$. The solvent was evaporated to give crude 1 as an oil form. 'H NMR $\left(\mathrm{CDCl}_{3}\right) \delta(\mathrm{ppm}) 1.46(\mathrm{~s}$, $18 \mathrm{H}), 3.09$ (t, 2H), $3.44(\mathrm{~s}, 4 \mathrm{H}), 3.65$ (t, 2H) (LC/MSD $\mathrm{M}+1$ ): cald. for 290.19 found 290.2 .

$N, N$-Bis[(tert-butoxycarbonyl)methyl]-2-bromoethylamine (2). To crude 1 dissolved in $\mathrm{CH}_{2} \mathrm{Cl}_{2}(100 \mathrm{~mL}), \mathrm{Ph}_{3} \mathrm{P}$ $(15.90 \mathrm{~g}, 60 \mathrm{mmol})$ was added, the solution was cooled down to $0{ }^{\circ} \mathrm{C}$, and NBS $(10.68 \mathrm{~g}, 60 \mathrm{mmol})$ was added small portion to portion for $5 \mathrm{~min}$. After stirring for $2 \mathrm{hrs}$ at $0^{\circ} \mathrm{C}$, the solvent was dried. According to the concentrating solution, a semisolid crude was formed and broken down into powder with ether $(300 \mathrm{~mL})$, often by crushing it with a glass stick. The solid residue was filtered and the ether phase separated. Evaporation of ether gave a pale yellow oil, which was purified by a silica gel column chromatography (Ether : Hexane $=4: 6)$ to obtain $2(14.5 \mathrm{~g}, 83 \%)$ as a colorless oil.

${ }^{1} \mathrm{H} \mathrm{NMR}\left(\mathrm{CDCl}_{3}\right) \delta(\mathrm{ppm}) 1.46(\mathrm{~s}, 18 \mathrm{H}), 3.12(\mathrm{t}, 2 \mathrm{H}), 3.43$ $(\mathrm{t}, 2 \mathrm{H}), 3.47(\mathrm{~s}, 4 \mathrm{H})$ (LC/MSD M+1): cald. for 352.10 found 352.1

2-(4-N-Boc-aminophenyl)ethanol (3). 2-(4-aminophenyl) ethanol $(2 \mathrm{~g}, 14.6 \mathrm{mmol})$ which was dissolved in TEA/ $\mathrm{MeOH}(10 \mathrm{~mL} / 15 \mathrm{~mL})$ was treated with $(\mathrm{Boc})_{2} \mathrm{O}(3.5 \mathrm{~g}$, $16.0 \mathrm{mmol}$ ) for $12 \mathrm{hrs}$ at $40^{\circ} \mathrm{C}$. The reaction mixture was evaporated and $\mathrm{CH}_{2} \mathrm{Cl}_{2}(50 \mathrm{~mL})$ was added. The organic layer was washed with $\mathrm{c}-\mathrm{NaCl}(20 \mathrm{~mL})$ and $\mathrm{H}_{2} \mathrm{O}(20 \mathrm{~mL})$. The solvent was dried in vacuo and purified by a column chromatography with $\mathrm{MC}: \mathrm{MeOH}(20: 1)$ to obtain $3(2.91$ $\mathrm{g}, 84 \%$ ) as a colorless oil.

${ }^{1} \mathrm{H}$ NMR $\left(\mathrm{CDCl}_{3}\right), \delta$ (ppm) $1.54(\mathrm{~s}, 9 \mathrm{H}), 2.84(\mathrm{t}, 2 \mathrm{H}), 3.84$ (t, 2H), 6.50 (br s, 1H, NH), $7.17(\mathrm{~d}, 2 \mathrm{H}), 7.32$ (d, 2H) (LC/ MSD M+1): cald. for 237.14 found $260.2(\mathrm{M}+\mathrm{Na})^{+}$.

1-(4- $N$-Boc-aminophenyl)-2-bromoethane (4). To a solution of $3(2.9 \mathrm{~g}, 12.2 \mathrm{mmol})$ in $\mathrm{CH}_{2} \mathrm{Cl}_{2}(30 \mathrm{~mL})$, $\mathrm{Ph}_{3} \mathrm{P}(3.21 \mathrm{~g}, 12.3 \mathrm{mmol})$ was added under a $\mathrm{N}_{2}$ condition at $0^{\circ} \mathrm{C}$. NBS $(2.18 \mathrm{~g}, 12.3 \mathrm{mmol})$ was added portionwisely for $5 \mathrm{~min}$. The resulting solution was stirred for $2 \mathrm{hrs}$ at $0^{\circ} \mathrm{C}$ and concentrated. Resulting crude was treated with diethyl ether, filtered, concentrated and purified by a silica gel column chromatography (ether : hexane $=1: 5)$ to give $4(3.30 \mathrm{~g}, 90$ $\%)$ as a white powder.

'H NMR $\left(\mathrm{CDCl}_{3}\right), \delta(\mathrm{ppm}) 1.54(\mathrm{~s}, 9 \mathrm{H}), 3.12(\mathrm{t}, 2 \mathrm{H}), 3.55$ $(\mathrm{t}, 2 \mathrm{H}), 6.52(\mathrm{br} \mathrm{s}, 1 \mathrm{H}, \mathrm{NH}), 7.15(\mathrm{~d}, 2 \mathrm{H}), 7.34(\mathrm{~d}, 2 \mathrm{H})(\mathrm{LC} /$ MSD M+1): cald. for 300.05 found 300.0 .

S-((4- $N$-Boc-aminophenyl)-1-ethyl)-cysteine methylester (5). Under a flushing $\mathrm{N}_{2}$ condition, Cysteine methylester $(343.0 \mathrm{mg}, 2.0 \mathrm{mmol})$ was activated with $0.5 \mathrm{M}$ sodium methoxide ( $8 \mathrm{~mL}, 4 \mathrm{mmol})$. From time to time, a small portion of $\mathrm{MeOH}$ was added in order to sustain its volume. After a stirring for $10 \mathrm{~min}, 4(600.0 \mathrm{mg}, 2.0 \mathrm{mmol})$ was added. The reaction mixture was continuously stirred for 5 hrs at room temperature. The solvent was removed in vacuo at $30^{\circ} \mathrm{C}$. The crude product was purified by a column chromatography eluting with $\mathrm{MC}: \mathrm{MeOH}(15: 1)$ to give 5 $(653 \mathrm{mg}, 92 \%)$ as a pale yellow oil.

'H NMR (CD $\left.{ }_{3} \mathrm{OD}\right), \delta(\mathrm{ppm}) 1.53(\mathrm{~s}, 9 \mathrm{H}), 2.81\left(\mathrm{~m},-\mathrm{CH}_{2}-\right.$ $\left.\mathrm{S}-\mathrm{CH}_{2}-\right), 2.92(\mathrm{t}, 2 \mathrm{H}), 3.66(\mathrm{t}, 1 \mathrm{H}), 3.75(\mathrm{~s}, 3 \mathrm{H}), 6.50(\mathrm{br} \mathrm{s}$, $1 \mathrm{H}, \mathrm{NH}), 7.13$ (d, 2H), 7.31 (d, 2H) (LC/MSD M+1): cald. for 355.2 found 355.0 .

$S$-( $N$-Boc-aminophenyl)-Cys(tBu $\mathbf{u}_{4}$-DTPA) methylester (6). To 2 ( $894 \mathrm{mg}, 2.55 \mathrm{mmol}$ ) which was dissolved in $\mathrm{CH}_{3} \mathrm{CN}(10 \mathrm{~mL}), 2 \mathrm{M}$ phosphate buffer $(\mathrm{pH}=8,5 \mathrm{~mL})$ and 5 (300 $\mathrm{mg}, 0.85 \mathrm{mmol}$ ) was added. After the mixture was stirred for 2 hrs, the same scale of a buffer was changed to adjust the $\mathrm{pH}$. The mixture was stirred for $48 \mathrm{hrs}$ and the $\mathrm{CH}_{3} \mathrm{CN}$ layer was isolated. The solvent was evaporated to afford a residue, which was partitioned between the $\mathrm{H}_{2} \mathrm{O}$ and the ethyl acetate. The organic layer was dried and chromatographed with ethylacetate : Hexane $(1: 9)$ to give $6(610 \mathrm{mg}$, $80 \%$ ) as a pale yellow oil.

'H NMR $\left(\mathrm{CDCl}_{3}\right), \delta(\mathrm{ppm}) 1.44(\mathrm{~s}, 36 \mathrm{H}), 1.50(\mathrm{~s}, 9 \mathrm{H})$, $2.80\left(\mathrm{br} \mathrm{m},-\mathrm{CH}_{2}-\mathrm{CH}_{2}-\mathrm{S}-\mathrm{CH}_{2}-\mathrm{CH}-\mathrm{N}-\left(\mathrm{C}_{2} \mathrm{H}_{4}\right)_{2}-\right), 3.42(\mathrm{~s}, 8 \mathrm{H})$, $3.68(\mathrm{~s}, 3 \mathrm{H}), 6.50(\mathrm{br} \mathrm{s}, 1 \mathrm{H}, \mathrm{NH}), 7.11(\mathrm{~d}, 2 \mathrm{H}), 7.27(\mathrm{~d}, 2 \mathrm{H})$ (LC/MSD M+1): cald. for 897.52 found 897.3.

$S$-Aminophenylethyl-Cys-DTPA (7). To a solution of 6 ( $300 \mathrm{mg}, 0.33 \mathrm{mmol}$ ) which was dissolved in $\mathrm{CH}_{3} \mathrm{OH}(20$ $\mathrm{mL}), \mathrm{c}-\mathrm{HCl}(10 \mathrm{~mL})$ was added and the mixture was heating at $70{ }^{\circ} \mathrm{C}$ for $1 \mathrm{hr}$. After the reaction was completed, the solvents were evaporated. Residue was recrystalized with diethylether to afford 7 as a white powder.

'H NMR ( $\left.\mathrm{D}_{2} \mathrm{O}\right), \delta$ (ppm) 2.76 (br m, $-\mathrm{CH}_{2}-\mathrm{CH}_{2}-\mathrm{S}-\mathrm{CH}_{2}-$ $\left.\mathrm{CH}-\mathrm{N}-\left(\mathrm{C}_{2} \mathrm{H}_{4}\right)_{2}-\right), 2.91(\mathrm{t}, 4 \mathrm{H}), 3.33(\mathrm{t}, 4 \mathrm{H}), 3.95(\mathrm{~s}, 8 \mathrm{H}), 7.19$ (m, aromatic, 4H) (LC/MSD M+1): cald. for 559.2 found 559.3 .

$S$-Aminophenylethyl-Cys $\left(t\right.$-Bu ${ }_{4}$-DTPA) methylester (8). To a solution of $6(300 \mathrm{mg}, 0.33 \mathrm{mmol})$ which was dissolved in ethylacetate $(20 \mathrm{~mL}), 3 \mathrm{~N} \mathrm{HCl}(5 \mathrm{~mL})$ was added and vigorously stirred for $30 \mathrm{~min}$. TLC analysis (ethylacetate $:$ hexane $=5: 5$ ) indicated that the reaction was complete. After the reaction was completed, $0.1 \mathrm{M} \mathrm{NaOH}$ was added to adjust the $\mathrm{pH}$ to $7-8$. Organic layer was separated, evaporated and purified with a column 
chromatography eluting with $\mathrm{MC}: \mathrm{MeOH}(10: 1)$ to give 7 $(160 \mathrm{mg}, 60 \%)$ as a pale yellow oil.

${ }^{1} \mathrm{H}$ NMR $\left(\mathrm{CDCl}_{3}\right), \delta(\mathrm{pmm}) 1.39$ (s, 36H), 2.73 (br m,

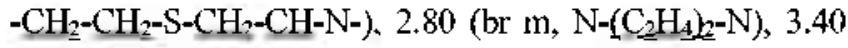
$(\mathrm{s}, 8 \mathrm{H}), 3.65(\mathrm{~s}, 3 \mathrm{H}), 6.57(\mathrm{~d}, 2 \mathrm{H}), 6.93(\mathrm{~d}, 2 \mathrm{H})$ (LC/MSD $\mathrm{M}+\mathrm{I}$ ): cald. for 797.47 found 797.5 .

Biotin-aminophenylethyl-Cys-DTPA (9). To a solution of $8(90 \mathrm{mg}, 0.112 \mathrm{mmol}$ ) and biotin ( $36 \mathrm{mg}, 0.146 \mathrm{mmol})$ in $\mathrm{NEt}_{3} / \mathrm{DMF}(100 \mu \mathrm{L} / 2 \mathrm{~mL})$ under a $\mathrm{N}_{2}$ condition, TBTU (47 $\mathrm{mg}, 0.146 \mathrm{mmol}$ ) was added and continuously stirred for 12 hrs at room temp. The mixture turned to a slightly pale yellow solution. The solvent was removed in vacuo and purified with a column chromatography with $\mathrm{MC}: \mathrm{MeOH}$ $(10: 1)$. Without any further purification, hydrolysis was performed with a consecutive treatment of $\mathrm{c}-\mathrm{HCl} / \mathrm{CH}_{2} \mathrm{Cl}_{2}$ at $80^{\circ} \mathrm{C}$ for $20 \mathrm{~min}$ and a recrystalization was performed with an addition of diethyl ether. The obtained product was a white powder and its yield was $34 \%(30 \mathrm{mg})$.

${ }^{1} \mathrm{H}$ NMR $\left(\mathrm{D}_{2} \mathrm{O}\right), \delta$ (ppm) 1.41-1.79 (m, biotin), 2.38 (t, biotin, $2 \mathrm{H}$ ), 2.68-2.91 (br m, $-\mathrm{CH}_{2}-\mathrm{CH}_{2}-\mathrm{S}-\mathrm{CH}_{2}-\mathrm{CH}-\mathrm{N}$ - and $4 \mathrm{H}), 3.10(\mathrm{~m}$, biotin, $2 \mathrm{H}), 3.33(\mathrm{t}, 4 \mathrm{H}), 4.10(\mathrm{~s}, 8 \mathrm{H}), 4.48(\mathrm{~m}$, biotin, $\mathrm{lH}), 4.31(\mathrm{~m}$, bjotin, $1 \mathrm{H}), 7.20(\mathrm{~d}$, aromatic, $2 \mathrm{H})$, 7.45 (d, aromatic, $2 \mathrm{H})$.

Production of ${ }^{166} \mathrm{Ho}\left(\mathrm{NO}_{3}\right),{ }_{3} \mathrm{H}_{2} \mathrm{O} .{ }^{166} \mathrm{Ho}\left(\mathrm{NO}_{3}\right)_{3} \cdot \mathrm{H}_{2} \mathrm{O}(\beta-$ decay : $1.85 \mathrm{MeV}(51 \%), 1.77 \mathrm{MeV}(48 \%) \gamma$-decay : 80.05 $\mathrm{KeV}, \mathrm{t}_{1 / 2}=26.8$ ) was produced by the ${ }^{165} \mathrm{Ho}\left(\mathrm{n}, \eta^{166} \mathrm{Ho}\right.$ reaction with a final product as a carrier-added form and currently produced at the HANARO research reactor $(30$ MW, Korea Atomic Energy Research Institute (KAERI)). $200 \mathrm{mg}$ of ${ }^{165} \mathrm{Ho}\left(\mathrm{NO}_{3}\right)_{3} \cdot 5 \mathrm{H}_{2} \mathrm{O}$ sealed in a titanium capsule encased in an aluminum capsule was irradiated for 72 hrs. Following irradiation, the target was allowed to cool for $24 \mathrm{hrs}$, and then extracted ${ }^{166} \mathrm{Ho}$ with $3 \mathrm{~mL}$ of $\mathrm{HCl}$ solution $(\mathrm{pH}=3)$.

Labeling of DTPA derivatives. $10 \mathrm{mg}$ of DTPA derivatives ( $S$-aminophenylethyl-Cys-DTPA (7) or Biotin-aminophenylethyl-Cys-DTPA (9)) were dissolved in pure water and adjusted to the $\mathrm{pH}$ of 5 with $0.05 \mathrm{~N} \mathrm{HCl}$. DTPA derivatives were filtered with a $0.22 \mu \mathrm{an}$ membrane filter (Gelman Science $\mathrm{Co}) ..10 \mathrm{mCi}(370 \mathrm{MBq})$ of ${ }^{166} \mathrm{Ho}\left(\mathrm{NO}_{3}\right)_{3}$ was mixed with the DTPA derivatives and mixed for $30 \mathrm{~min}$ at room temp. Labeling yield and radiochemical purity of each ${ }^{166} \mathrm{Ho}$ complex was analyzed by an ITLC scanner (Trance master 200 , Berthold) with ITLC-SG as a stationary phase and $75 \%$ $\mathrm{MeOH}$ as a developing solvent.

$S$-aminophenylethyl-Cys-DTPA; Distance from the solvent front $=103 \mathrm{~mm}, \mathrm{Rf}=0.93$, labeling yield $>99 \%$
Biotin-aminophenylethyl-Cys-DTPA; Distance from the solvent front $=108 \mathrm{~mm}, \mathrm{Rf}=0.97$

labeling yield $>99 \%$

\section{Results and Discussion}

As a part of our ongoing plans, we intend to develop a new bifunctional chelating system which has a more powerful metal-chelating effect and lasts longer in an in vivo condition. To meet this purpose, we have focused on DTPA (octadentate-ligand) used as an MRI contrasting agent and radiophramaceuticals. DTPA-metal complex has a good stability for up to $24 \mathrm{hrs}$ under the $\mathrm{pH}$ range of 1.7-7.5 at 37 ${ }^{\circ} \mathrm{C} .{ }^{20}$

In order to support the chelating power, functional group must be kept intact. As depicted in the retrosynthesis in Figure 1, we had a chance to establish the DTPA which was composed of glycine and ethylimino diacetate. In the DTPA structure, glycine, a sort of amino acid, could be altered to other amino acids and so 11 was designed as a DTPA synthon. Moreover, we also considered that 11 might be valuable as a bifunctional chelating agent when $\mathbf{1 2}$ was replaced with amino acid including another functional group, such as cysteine, serine, histidine, aspartic acid, etc.

On the basis of this thesis, we designed a reaction pathway as shown by Scheme 1. N,N-Bis[(tert-butoxycarbonyl)methy]]-2-bromoethyl-amine (2) was prepared with $N, N^{\prime}-$ bisalkylation by referring to Rapoport's report. ${ }^{3} \mathrm{I}-(4-N$-Bocaminophenyl)-2-bromoethane (4) was prepared by treating $\mathrm{N}$-protection with Boc and bromination with NBS. In the preparation of 4, 2-(4-aminophenyl) ethanol was chosen as a synthetic chaser to easily establish the progress of the reaction under the UV condition and as a binder for the bioactive molecules. Cysteine derivative 5 was obtained by the reaction of $\mathbf{4}$ and cysteine methylester under $2 \mathrm{eq}$ of $\mathrm{NaOCH}_{3}$. This reaction was influenced by the form of the cysteine ( $\mathrm{HCl}$ salt, neutral or cysteine metheyl ester) and the amount of $\mathrm{NaOCH}_{3}$. We used cysteine methyl ester hydrochloric salt in which I eq $\mathrm{NaOCH}_{3}$ was used for the hydrochloric salt and $\mathrm{I}$ eq for activating thiol to give 5 with an over $90 \%$ yield. Coupling of 5 and $\mathbf{2}$ under buffer system afforded the desired $N, N^{\prime}$-bisalkylating compound 6 with a good yield.

Hydrolysis and coupling is shown in Scheme 2. The selective hydrolysis 8 was performed by using $3 \mathrm{~N} \mathrm{HCl}$ ( 1.5 $\mathrm{mL}$ ) per $0.1 \mathrm{mmol}$ of the reactant and it was identified with TLC ((ethylacetate: hexane $=5: 5,6: \mathrm{R}_{\mathrm{f}}=0.45,8: \mathrm{R}_{\mathrm{f}}=$<smiles>O=C(O)CN(CCN(CC(=O)O)CC(=O)O)CC(=O)O</smiles>

10

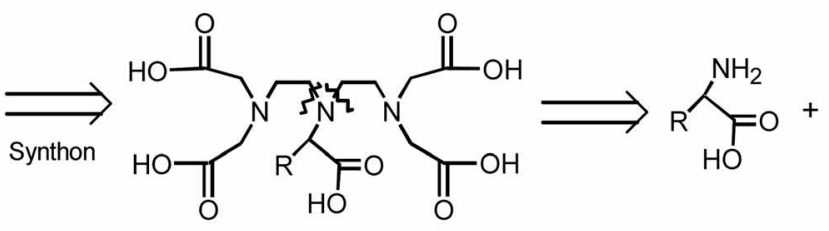

11<smiles>O=C(O)CN(CBr)CC(=O)O</smiles>

13

Figure 1. Retrosynthesis of the DTPA R = Functionalized alkyl side chain. 

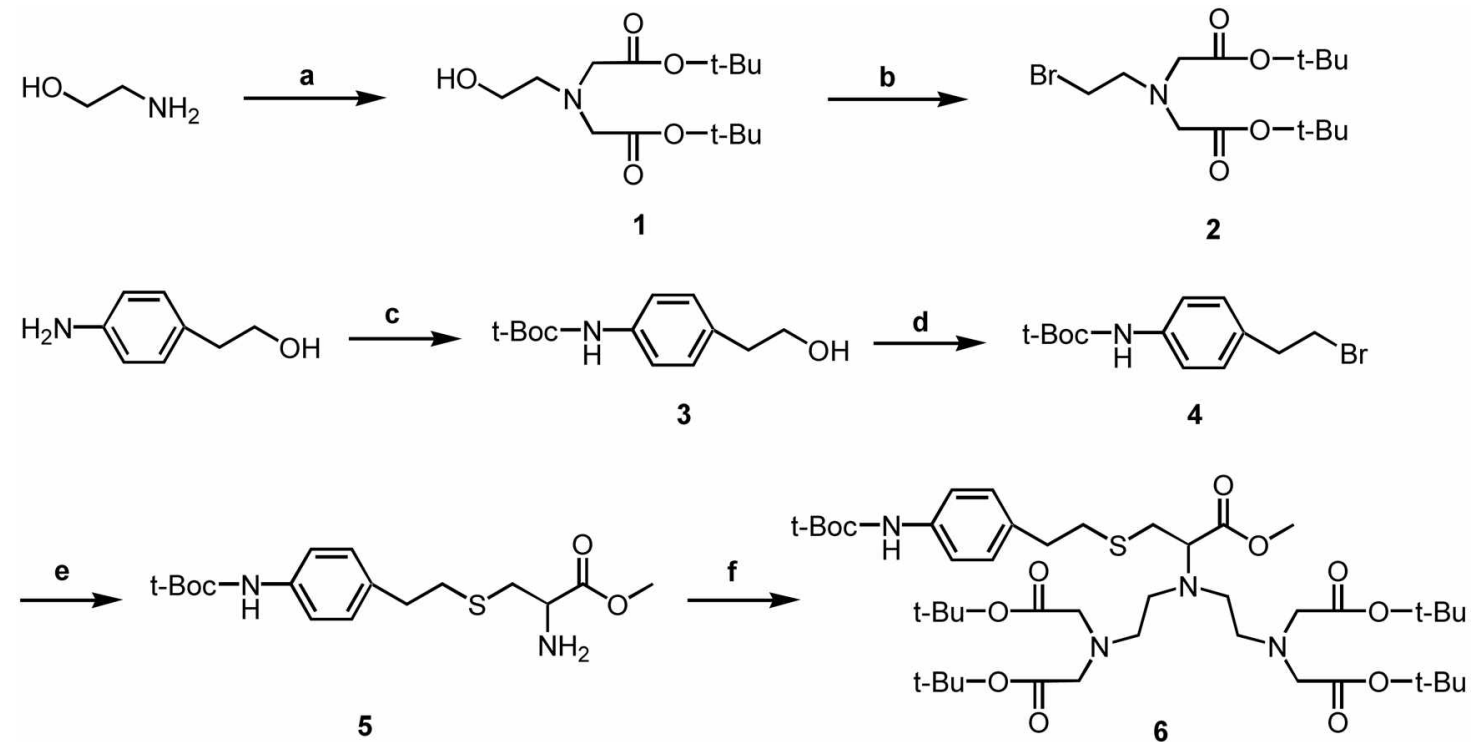

Scheme 1. Reaction pathway of the cystcine based DTPA. Reagents and conditions; (a) $\mathrm{BrCH}_{2} \mathrm{COOtBu} / \mathrm{K}_{2} \mathrm{CO}_{3} / \mathrm{DMF} / \mathrm{RT}$, 48 hrs; (b) NBS/

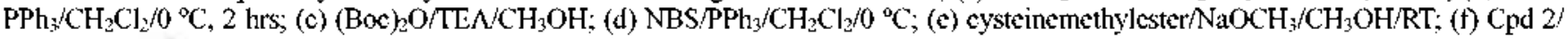
phosphate buffer $\mathrm{pH}=8 / \mathrm{RT}$
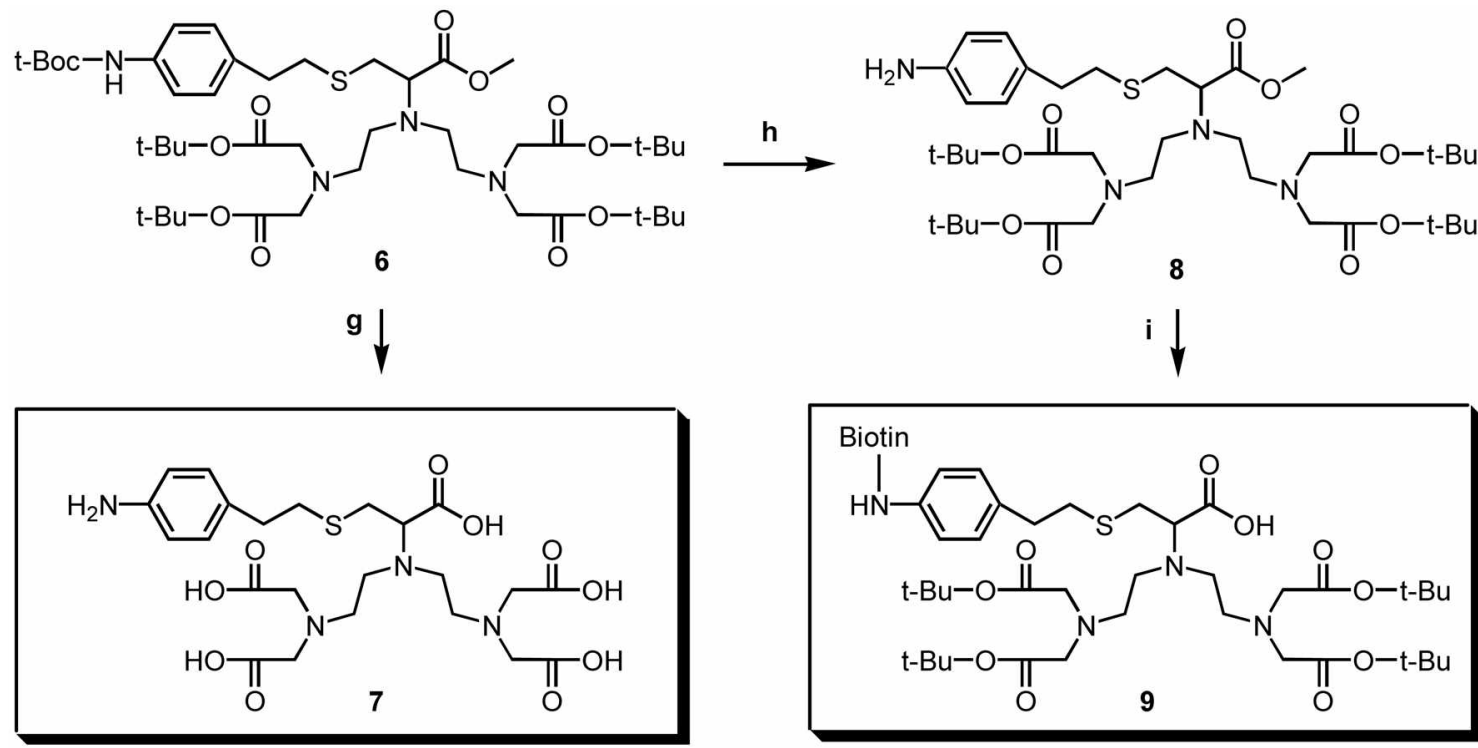

Scheme 2. Hydrolysis and biotinylation of the DTPA derivatives. Reagents and condtions: $(\mathrm{g}) \mathrm{c}-\mathrm{HCl} / 70^{\circ} \mathrm{C} / 1 \mathrm{hr}(\mathrm{h}) 3 \mathrm{~N} \mathrm{HCl} / \mathrm{Ethylacetate} /$ $\mathrm{RT}, 30 \mathrm{hr}$; (i) 1. Biotin/TBTU/TE $/ / \mathrm{CH}_{2} \mathrm{Cl}_{2} / \mathrm{RT} ; 2 . \mathrm{c}-\mathrm{HCl} / 70^{\circ} \mathrm{C}$.

starting), $\left(\mathrm{MC}: \mathrm{MeOH}=10: 1,6: \mathrm{R}_{\mathrm{f}}=0.7,8: \mathrm{R}_{\mathrm{r}}=0.3\right)$ ). The coupling with the biomolecules was achieved by the treatment of TBTU. We also used DCC as coupling agent, but TBTU showed a better result in the preparation of 9.

${ }^{166} \mathrm{Ho}$-DTPA derivative complexes were prepared by simply mixing ${ }^{166} \mathrm{Ho}$ and DTPA at room temp. The ITLC patterns of ${ }^{166} \mathrm{Ho},{ }^{166} \mathrm{Ho}$-S-aminophenylethyl-Cys-DTPA and ${ }^{166}$ Ho-Biotin-aminophenylethyl-Cys-DTPA showed that the $R_{f}$ values of these complexes were $0.09,0.93$ and 0.97 , respectively (Fig. 2). The radiochemical stability of these complexes was maintained for over $6 \mathrm{hrs}$ at $36^{\circ} \mathrm{C}$.

\section{Conclusion}

We have established the preparation procedure of an amino acid based DTPA by a synthesis of $S$-aminophenylethyl-Cys( $t$-Bu $\left.{ }_{4}-\mathrm{DTPA}\right)$ methylester (8). This DTPA derivative has merits, in that its aromatic moiety is useful as a synthetic chaser in reaction progress and its selective hydrolysis is also helpful for introducing bioactive molecules without other side reactions. In conclusion, $S$ aminophenylethyl-Cys $\left(t-B u_{4}-D T P A\right)$ methylester $(8)$ as a $\mathrm{BFCA}$ will show good properties for a specific regional system in radioimmunotheraphy. 

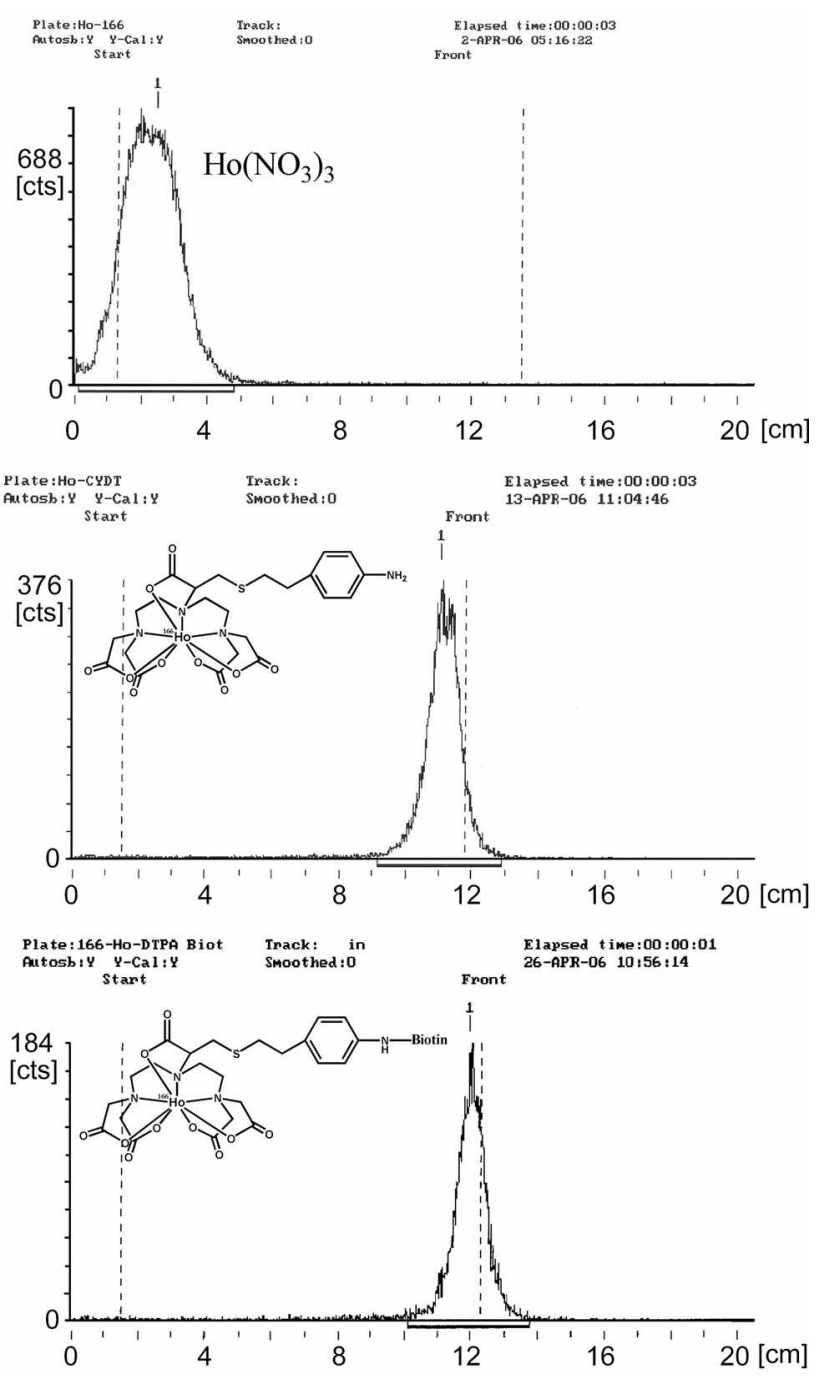

Figure 2. The ITLC patterns of ${ }^{166} \mathrm{Ho}\left(\mathrm{NO}_{3}\right)_{3}$ and ${ }^{166} \mathrm{Ho-complexes.}$ Conditions: developing solvent $(75 \% \mathrm{MeOH})$, developing time (about $40 \mathrm{~min}$ ), stationary phase (ITLC-SG), starting point (1.5 $\mathrm{cm}$ ), distance from solvent front (about $11 \mathrm{~cm}$ ).

\section{References}

I. Brechbiel. M. W.; Gansow, O. A. Bioconiugate Chem. 1991. 2. 187.

2. Pippin, C. G.; Parker, T. A.; McMurry, T. J.; Brechbiel, M. W. Bioconjugate Chem. 1992, 3,342 .

3. Williams, M. A.; Rapoport, H. J. Org. Chem. 1993, 58. I151.

4. Davies, J. S.; Al-Jamari, L. J. Pept. Sci. 2002, 8,663.

5. Liu, S.; Cheung, E.; Rajopadhye, M.; Williams, N. E.; Overoye, K. L.; Edwards, D. S. Bioconingate Chem. 2001, I2, 84.

6. Yang, J. Q.; Li, Y,; Lu, J.; Wang, X. B. J. Radioanal. Nicl. Ch $2005,265(3), 467$.

7. Fu, Y.; Laurent, S.; Muller, R. N. Etr. J. Org. Chent. 2002. 3966.

8. Scozzafava, A.; Menabuoni, L.; Mincione, F.; Mincione, G.; Supuran, C. T. Bioorg. Med. Chem. Lett. 2001, M, 575.

9. Sundberg, M. W.; Meares, C. F.; Goodwin, D. A.; Diamanti, C. I. J. Med. Chem. 1974, 17, 1304 .

10. Chhikara, B. S.; Kumar, N.; Tandon, V.; Mishra, A. K. Bioorgan. Med. Chem, $2005,13,4713$.

I1. Lub-de Hooge, M. N.; Kosterink, J. G. W.; Perik, P. J.; Nijnuis, H.; Tran, L.; Bark, J.; Suurmeijer, A. J. H.; de Jong, S. D.; Jager, P. L.; de Vries, E. G. E. Brit. J. Pharmacol. 2004. 143,99.

12. Tang, H. A.; Yang, S.; Yang, R. D. Syrthetic Commun, 2003, $33(16), 281 \mathrm{l}$,

13. Volkert, W. A.; Hoflmann, T. J. Chem. Rev, 1999, 99, 2269.

14. Breitz, H. B.; Welden, P. L.; Beaumier, P. L.; Axworthy, D. B.; Seiler, C.; Su, F. M.; Graves, S.; Bryan, K.; Reno, J. M. J. Nucl. Med. 2000, 4l, 131 .

15. Grana, C.; Chinol, M.; Robertson, C.; Bartolomei, M.; De Cicco, C.; Fiorenza, M.; Galti, M.; Cliceti, P.; Paganelli, G. Br. J. Cancer 2002, 86, 207

16. Ferro-Flores, G.; de Murphy, C. A.; Pedraza-Lopez, M.; MonroyGuzman, F.; Melezdez-Alafort, L.; Tendilla, J. J.; Jimenez-Varela, R. In. J. Pharm. 2003, 255, 129.

17. Boerman, O. C.; van Schaijk, F. G.; Oyen, W. J. G.; Corstens, F. H. M. J. Nucl. Med. $2003,44,400$.

18. Correa-González, L.; de Murphy, C. A.; Ferro-Flores, G.; PedrazaLopez, M.; Murphy-Stack, E.; Mino-Leon, D.; Perez-Villasenor, G.; Diaz-Torres, Y.; Munoz-Olvera, R. Nicl. Med. Biol. 2003, 30. 135.

19. Hainsworth, J.; Harrison, P.; Mather, S. J. Bioconjugate Chem. $2005,16,1468$

20. Hong, Y. D.; Park, K. B.; Jang B. S.; Choi, S. J.; Choi, S. M.; Kim, Y. M. Nucl. Med. Biol. 2002. 29.833. 